\title{
Association between Genetic Polymorphisms and Response to Anti-TNFs in Patients with Inflammatory Bowel Disease
}

\author{
Rocío Prieto-Pérez $^{1,2}$, Berta Almoguera ${ }^{3}$, Teresa Cabaleiro ${ }^{1,2,4}$, Hakon Hakonarson ${ }^{3}$ and \\ Francisco Abad-Santos 1,2,4,* \\ 1 Clinical Pharmacology Service, Hospital Universitario de la Princesa, Instituto de Investigación Sanitaria la \\ Princesa (IP), Madrid 28006, Spain; rociomaria.prieto@gmail.com (R.P.-P.); \\ teresacabaleiro@hotmail.com (T.C.) \\ 2 Instituto Teófilo Hernando, University Autónoma de Madrid (UAM), Madrid 28029, Spain \\ 3 Center for Applied Genomics, The Children's Hospital of Philadelphia, Philadelphia, PA 19104, USA; \\ balmoguera@hotmail.com (B.A.); hakonarson@email.chop.edu (H.H.) \\ 4 Centro de Investigación Biomédica en Red de Enfermedades Hepáticas y Digestivas (CIBERehd), \\ Instituto de Salud Carlos III, Madrid 28006, Spain \\ * Correspondence: francisco.abad@salud.madrid.org; Tel.: +34-9-1520-2425; Fax: +34-9-1520-2540
}

Academic Editor: William Chi-shing Cho

Received: 11 January 2016; Accepted: 3 February 2016; Published: 6 February 2016

\begin{abstract}
Tumor necrosis factor (TNF) $\alpha$ is a major proinflammatory cytokine involved in the immune response in inflammatory bowel disease (IBD). Anti-TNF drugs such as infliximab and adalimumab are used to treat IBD; however, approximately $30 \%$ of patients do not respond to treatment. Individual genetic differences could contribute to lack of efficacy. Genetic studies have tried to uncover the factors underlying differences in response, however, knowledge remains limited, and the results obtained should be validated, so that pharmacogenetic information can be applied in clinical practice. In this review, we gather current knowledge in the pharmacogenetics of anti-TNF drugs in patients with IBD. We observed a connection between the major genes described as possible predictors of response to anti-TNF drugs in IBD and the cytokines and molecules involved in the Thelper (Th) 17 pathway.
\end{abstract}

Keywords: inflammatory bowel disease; polymorphisms; pharmacogenomics; adalimumab; infliximab

\section{Introduction}

Inflammatory bowel disease (IBD) comprises ulcerative colitis (UC) and Crohn's disease (CD). Patients with IBD display some common symptoms such as severe diarrhea, pain, fatigue, and weight loss [1], but the localization is slightly different: whereas CD affects the whole gastrointestinal tract, UC primarily affects the distal intestine and ileum [2]. The prevalence of IBD varies with geographic location with higher rates for UC in Europe: 505/100,000 individuals versus 249/100,000 in North America and similar rates for CD 319-322/100,000 in both areas [3].

Genetic, environmental, and immunoregulatory factors play a key role in the development of IBD. Although its cause is unknown, IBD is characterized by a dysregulated response of the mucosal immune system to intraluminal bacterial antigens [4]. Specifically, the up-regulation of cytokines such as tumor necrosis factor (TNF) $\alpha$, interleukin (IL) $1 \beta$, and IL6 [5,6], which activate Thelper (Th) 1 and 17 cells have a central role in IBD [7].

Anti-TNF drugs are indicated and recommended in patients with moderate-to-severe IBD who do not tolerate or do not respond to conventional therapies. Infliximab and adalimumab are monoclonal antibodies that bind with high affinity to TNF $\alpha$ and block its interaction with cell surface receptors. 
Although both are effective in IBD [8,9], approximately $30 \%$ of patients do not respond to anti-TNF drugs $(\sim 30 \%)$ and may develop adverse reactions to the treatment [10-12]. It is increasingly being recognized that genetics may account for these inter-individual differences in the response to anti-TNF treatment [13]. Therefore, identification of genetic markers predictive of drug response, could help optimize treatments and prevent adverse reactions [14].

Based on current knowledge of pharmacogenetics in IBD, this review highlights the importance of Th17 cells and their relationship with the response to anti-TNF medication.

\section{Immune System and Th17 Cells in IBD}

IBD is characterized by excessive and abnormal immune response against commensal flora in genetically susceptible individuals, which involves both innate and adaptive immunity [4]. Adaptive immunity includes immunoglobulins produced by B cells and a mixture of Th1 cells, which are the predominant type in CD, and Th2, primarily observed in UC [15]. Th17, a CD4 T-cell lineage distinct from Th1 and Th2, which is promoted by IL23 and characterized by the production of IL17, has also been observed in IBD [16]. A schematic representation of the interconnection between the three Th cytokine profiles in IBD is illustrated in Figure 1.

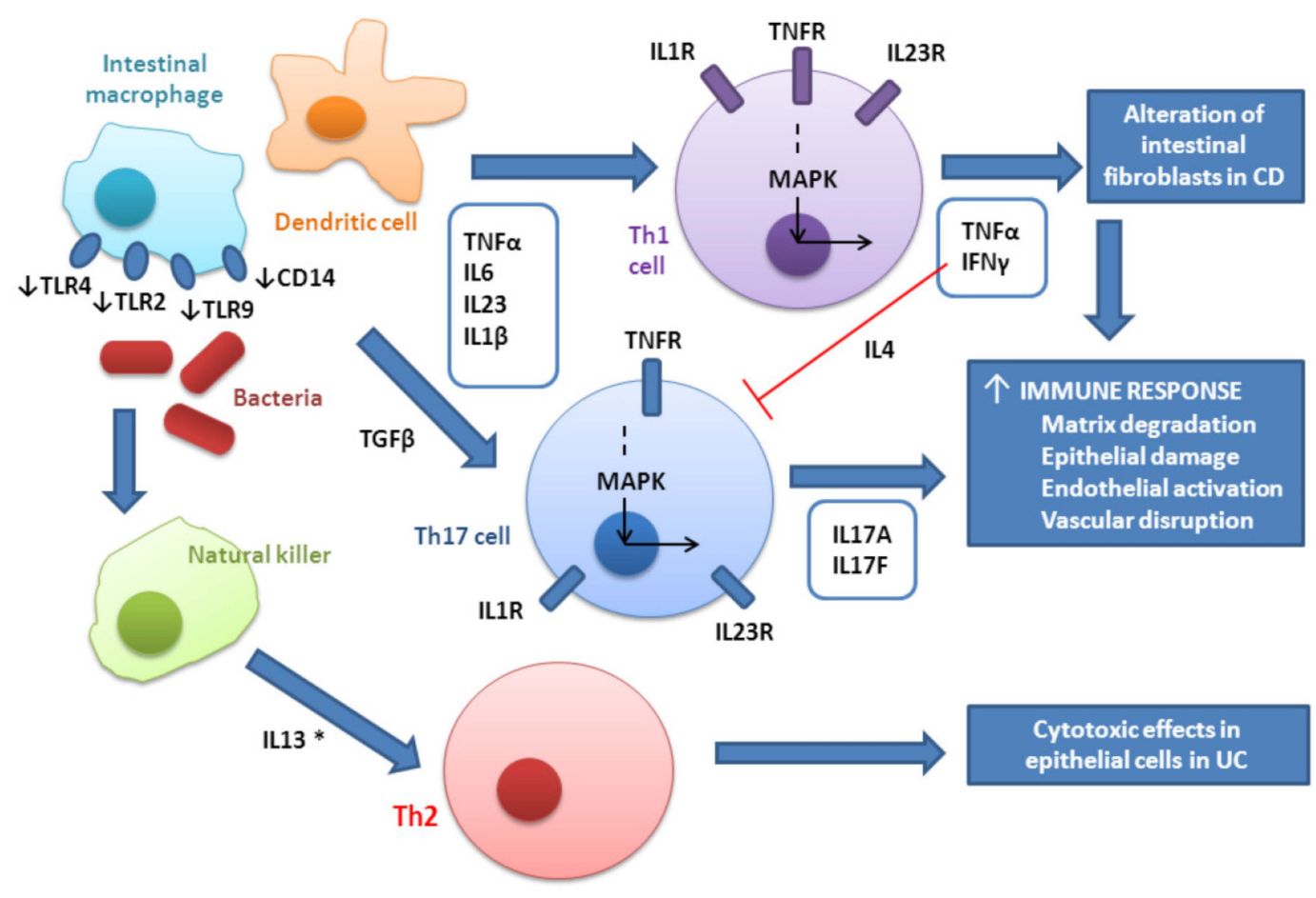

Figure 1. Immune response in inflammatory bowel disease (IBD). TLR: toll-like receptor; CD14: CD14 molecule; TNF: tumor necrosis factor; IL: interleukin; Th: lymphocyte T helper; IL1R: interleukin 1 receptor; TNFR: tumor necrosis factor receptor; IL23R: interleukin 23 receptor; IFN: interferon; MAPK: mitogen-activated protein kinase; CD: Crohn's disease; UC: ulcerative colitis; $\uparrow:$ upregulation; $\downarrow$ : downregulation; *: regulation Th1 and Th17; $\rightarrow$ : stimulation; $\perp$ : inhibition.

The presence of microbes triggers Th1 development and the production of IL-12 and interferon $\gamma($ IFN $\gamma)$, which then activate macrophages. Macrophage and dendritic cells produce the pro-inflammatory cytokines TNF $\alpha$, IL6, IL23, and IL1 $\beta$ that promote differentiation of naïve CD4+ T cells into Th1 and Th17 [17]. Other cytokines such as Toll-like receptor (TLR) 3, TLR4, TLR9, and transforming growth factor $\beta$ (TGF $\beta$ ) are also involved in Th17 differentiation [18-20]. Smythies et al. reported that bacterial recognition receptors (TLR and CD14) are downregulated in resident intestinal macrophages. This allows these types of cells to reside in the distal ileum and colon, where the bacterial 
concentration is high [21]. Although TLRs are essential for the recognition of pathogens and activation of innate immunity, different types of TLRs bind to different molecules. For example, TLR4 binds to bacterial lipopolysaccharide, TLR2 binds to peptidoglycan [7], and TLR9 binds to various bacterial DNA species [22]. Polymorphisms in these receptors could influence the response to anti-TNF therapy in patients with IBD through alteration of the NFK $\beta$ pathway [23].

Activated Th1 cells produce IFN $\gamma$ and TNF $\alpha$. IFN $\gamma$ inhibits differentiation to Th17, which is suggested to enhance the development of pathogenic Th17 cells and exacerbate autoimmunity [24] and also stimulates macrophage and dendritic cells, increasing the production of pro-inflammatory cytokines and, therefore, the immune response [6].

The Th2 response observed in UC seems to be an atypical cytotoxic response [7] mediated by non-classic natural killer T cells (activated by antigen-presenting cells) that produce IL13 [25]. Although the role of IL13 is not clear, variations in the IL13 gene result in deregulation of the Th1 and Th17 pathways in related autoimmune diseases such as psoriatic arthritis [26].

Th17-cell development is driven by TGF $\beta$ and IL-6, whereas IL-23 seems to expand and maintain Th17-cell populations. Th17 cells produce several cytokines, such as IL17A and IL17F [27], with promotes the expression of TNF $\alpha$. TNF $\alpha$ acts on intestinal fibroblasts, leading to the release of other cytokines (IL13 or TGF $\beta$ ) and formation of strictures and fibrosis in CD [28]. Moreover, TNF $\alpha$ and the proinflammatory cytokines IL6 and IL1 produce matrix degradation, epithelial damage, endothelial activation, and vascular disruption in CD (Figure 1) [6].

\section{Polymorphisms Associated with Response to Anti-TNF Drugs in IBD}

There are currently three TNF $\alpha$ antagonists available in the treatment of IBD: infliximab, adalimumab and golimumab, which are full-length antibodies and their Fc region is capable of complement fixation and Fc-receptor mediated biologic activities. These compounds exert a down-regulation of inflammatory cells in the inflamed bowel mucosa induced by apoptosis in TNF carrying cells [29].

Anti-TNF drugs are safe and effective for treatment of IBD [8,30,31] but close to $30 \%$ of patients are non-responders [23,30]. Genetics and immune system play an important role in the development of IBD, and differences in response could be due to the patient's genetic background [32]. However, knowledge of the pharmacogenetics of anti-TNF therapy in IBD is limited, and more studies are necessary before personalized medication can be applied to clinical practice. Such approaches may be able to predict which patients with IBD would be more likely to respond to anti-TNF drugs in order to minimize the risks for the patients and the development of adverse reactions.

Table 1 presents the most updated information on the pharmacogenetics of IBD with respect to anti-TNF drugs (infliximab and/or adalimumab).

In a study of luminal CD $(n=204)$ receiving infliximab, patients with the TT genotype for rs4645983 (CASP9) or CC/CT genotype for rs763110 (FASLG) showed a better response to the treatment at week 4 [30]. Hlavaty et al. also reported that concomitant therapy of infliximab with azathioprine/mercaptopurine could improve the effect of unfavorable genotypes [30]. Another variant in FASLG, rs763110, was able to predict the therapeutic response to infliximab in a sample of patients with fistulizing $C D(n=83)$ at week 10 [30]. Similarly, Japanese patients with CD and the GG genotype for FCGR3A had a better response at week 8 [33].

ATG16L1 was recently postulated as a predictor of therapeutic response for adalimumab. ATG16L1 is an autophagy-related gene that processes intracellular bacteria [34] and is expressed in intestinal epithelial cell lines [35]. ATG16L1 was associated with higher susceptibility to CD [34,35], and patients with the TT genotype for rs10210302 responded better to adalimumab after 12, 20, and 30 weeks of treatment compared to the CC genotype [36].

The cytokine IL23 is involved in the pathogenesis of IBD (Figure 1). The single-nucleotide polymorphism (SNP) rs11209026 in the IL23R gene, which encodes a subunit of the receptor for IL23, has been associated with CD [37] and Duerr et al. suggested that IL23R could be a therapeutic 
target in IBD [37]. Moreover, several genetic variants in IL23R have been associated with response to infliximab in patients with moderate-to-severe UC $(n=90)$ at week 14 (Table 1) [31]. For instance, AA genotype for rs1004819, rs10889677, and rs11209032, GG genotype for rs2201841, and CC genotype for rs1495965 in IL23R gene increased the probability to respond to infliximab [31]. However, GG genotype for rs7517847 and rs11465804, CC genotype for rs10489629, and AA genotype for rs1343151 in IL23R decreased the probability to respond to this drug [31]. Therefore, IL23R could be an interesting molecule for further follow-up.

IL23 is released with other relevant pro-inflammatory cytokines like IL6, TNF $\alpha$, and IL1 $\beta$ during the immune response in IBD (Figure 1). In a recent study, Bank et al. found the TC/CC genotype for rs10499563 in IL6 and the GA/AA genotype with a better response to anti-TNF. The authors investigated the role of three genetic variants in $I L 1 \beta$, for rs4848306, rs1143623 and rs1143627, but only found a positive association for rs4848306 [23]. Bank and colleagues also studied the effect of rs4251961 in IL1RN, which regulates IL1 $\beta$ signaling in immune and inflammatory responses, and observed that allele $C$ was associated with poorer responses to therapy [23].

In contrast to Bank's findings on IL1 $\beta$, Lacruz-Guzmán and colleagues found a poorer response to infliximab in carriers of the $C$ allele of rs1143634, in CD patients at 14 weeks [38]. These authors also evaluated the association between several polymorphisms in TNF $\alpha$ (rs361525, rs1800629, rs1799724) and response to infliximab but did not find any significant association [38], as opposed to what has been reported by several other authors (Table 1) [23,39,40].

Taylor et al. described an association between homozygosity for the NcoI-TNFc-aa13L-aa26 haplotype (1-1-1-1) in the LTA gene, which encodes a member of the TNF family, the lymphotoxin- $\alpha$ precursor, and poor response to infliximab [41]. Other TNF family members such as the receptors $1 \mathrm{~A}$ and 1B have been associated with response to this compound (Table 1) [23,32]: rs767455 in TNFRSF1A and rs1061622, rs1061624, and rs3397 in TNFRSF1B [32] (Table 1).

A polymorphism in TNFAIP3, rs6927172 was reported by Banks et al. associated with poor response to anti-TNF therapy [23]. TNFAIP3 encodes the $\alpha$-induced protein, whose expression is induced by $\mathrm{TNF} \alpha$, and that inhibits NFK $\beta$ activation (reference). Banks also investigated other components of the NFK $\beta$ pathway and found no association with polymorphisms in the NFKBIA and NFKB1 genes but a positive association between rs7222094 in MAP3K14 and anti-TNF medication response [23].

TLR9, TLR2, and TLR4 involved in the recognition of pathogens and activation of the immune response (Figure 1), have also been associated with response to anti-TNF therapy in IBD (Table 1) [23]. TLR4 cooperates with LY96 and CD14 to mediate the innate immune response to bacterial lipopolysaccharide. The A allele of rs2569190 in CD14 and the G allele of rs11465996 in LY96 have been associated with anti-TNF response (Table 1) [23]. However, rs5744168 in TLR5 and rs12377632 in TLR4 did not show any association with response [23]. A study on patients with CD with adalimumab, focused on genetic variants in CD14 and TLR4 was not able to replicate the above findings [42].

Fujino et al. found mRNA expression and serum levels of IL17 to be increased in patients with IBD [43] and suggested that IL17 might be associated with altered immune and inflammatory responses in the intestinal mucosa (Figure 1). This cytokine seems to play a relevant role in the response to anti-TNF drugs in patients with IBD (Table 1). Patients with this disease and A allele carriers for rs2275913 in IL17A had a poorer response to treatment with anti-TNF drugs [23].

Finally, INF $\gamma$ is also produced by Th1 and regulates Th17 cells (Figure 1). The SNP rs2430561 in this cytokine seems to influence the response to anti-TNF therapy in patients with IBD [23]. 
Table 1. Association between single-nucleotide polymorphisms SNPs and response to anti-tumor necrosis factor (TNF) drugs (infliximab and/or adalimumab) in patients with inflammatory bowel disease.

\begin{tabular}{|c|c|c|c|c|c|c|c|c|c|c|}
\hline Gene & SNP & CHR & Minor Allele & MAF & $\begin{array}{c}\text { Sample Size } \\
\text { Studied }\end{array}$ & Population & $\begin{array}{l}\text { Effect on the } \\
\text { Response }\end{array}$ & Disease/Drug & $\begin{array}{c}\text { Involved in Th17 } \\
\text { Responses }\end{array}$ & Reference \\
\hline CASP9 & rs4645983 & 1 & A & 0.218 & 287 & Caucasian & $\downarrow C$ allele & $\mathrm{CD} / \mathrm{I}$ & $\mathrm{NO}$ & [30] \\
\hline FASLG & rs763110 & 1 & C & 0.607 & 287 & Caucasian & $\uparrow \mathrm{C}$ allele & $\mathrm{CD} / \mathrm{I}$ & NO & [30] \\
\hline FCGR3A & rs396991 & 1 & $\mathrm{~T}$ & - & 102 & Japanese & $\uparrow \mathrm{GG}$ genotype & $\mathrm{CD} / \mathrm{I}$ & NO & {$[33]$} \\
\hline IL23R & $\begin{array}{l}\text { rs359991 } \\
\text { rs1004819 }\end{array}$ & 1 & A & 0.288 & $\begin{array}{l}102 \\
90\end{array}$ & $\begin{array}{l}\text { Japanese } \\
\text { Caucasian }\end{array}$ & $\uparrow$ AA genotype & $\mathrm{UC} / \mathrm{I}$ & YES & [31] \\
\hline$I L 23 R$ & rs2201841 & 1 & G & 0.296 & 90 & Caucasian & $\uparrow \mathrm{GG}$ genotype & $\mathrm{UC} / \mathrm{I}$ & YES & [31] \\
\hline IL23R & $\begin{array}{l}\text { rs10889677 }\end{array}$ & 1 & A & 0.292 & 90 & Caucasian & $\uparrow$ AA genotype & $\mathrm{UC} / \mathrm{I}$ & YES & [31] \\
\hline IL23R & rs11209032 & 1 & A & 0.306 & 90 & Caucasian & $\uparrow \mathrm{AA}$ genotype & $\mathrm{UC} / \mathrm{I}$ & YES & [31] \\
\hline IL $23 R$ & rs1495965 & 1 & C & 0.410 & 90 & Caucasian & $\uparrow$ CC genotype & $\mathrm{UC} / \mathrm{I}$ & YES & [31] \\
\hline IL23R & rs7517847 & 1 & G & 0.442 & 90 & Caucasian & $\downarrow$ GG genotype & $\mathrm{UC} / \mathrm{I}$ & YES & [31] \\
\hline IL23R & rs10489629 & 1 & C & 0.473 & 90 & Caucasian & $\downarrow$ CC genotype & $\mathrm{UC} / \mathrm{I}$ & YES & [31] \\
\hline IL23R & rs11465804 & 1 & G & 0.045 & 90 & Caucasian & $\downarrow$ GG genotype & $\mathrm{UC} / \mathrm{I}$ & YES & [31] \\
\hline$I L 23 R$ & rs1343151 & 1 & A & 0.327 & 90 & Caucasian & $\downarrow$ AA genotype & $\mathrm{UC} / \mathrm{I}$ & YES & [31] \\
\hline TNFRSF1B & rs1061622 & 1 & G & 0.239 & 81 & Japanese & $\downarrow$ G allele & $\mathrm{CD} / \mathrm{I}$ & YES & [32] \\
\hline TNFRSF1B & rs1061624 & 1 & G & 0.477 & 81 & Japanese & $\#$ & $\mathrm{CD} / \mathrm{I}$ & YES & {$[32]$} \\
\hline TNFRSF1B & rs3397 & 1 & $\mathrm{~T}$ & 0.526 & 81 & Japanese & \# & $\mathrm{CD} / \mathrm{I}$ & YES & {$[32]$} \\
\hline ATG16L1 & rs10210302 & 2 & $\mathrm{~T}$ & 0.392 & 102 & Caucasian & $\uparrow \mathrm{T}$ allele & $\mathrm{CD} / \mathrm{A}$ & NO & [36] \\
\hline IL1B & rs4848306 & 2 & A & 0.464 & 738 & Caucasian & $\uparrow$ A allele & $\mathrm{CD}, \mathrm{UC} / \mathrm{A}, \mathrm{I}$ & YES & {$[23]$} \\
\hline IL1B & rs1143634 & 2 & A & 0.208 & 47 & Caucasian & C allele & CD/I & $\begin{array}{l}\text { YES } \\
\text { YES }\end{array}$ & {$[38]$} \\
\hline IL1RN & rs4251961 & 2 & C & 0.385 & 738 & Caucasian & $\downarrow$ C allele & $\mathrm{CD}, \mathrm{UC} / \mathrm{A}, \mathrm{I}$ & YES & [23] \\
\hline TLR9 & rs187084 & 3 & G & 0.341 & 738 & Caucasian & $\uparrow$ TC genotype & $\mathrm{CD}, \mathrm{UC} / \mathrm{A}, \mathrm{I}$ & YES & [23] \\
\hline TLR9 & rs352139 & 3 & $\mathrm{~T}$ & 0.518 & 738 & Caucasian & $\downarrow$ AA gentoype & CD, UC/A, I & YES & [23] \\
\hline TLR2 & rs4696480 & 4 & A & 0.000 & 738 & Caucasian & $\downarrow$ TT genotype & $\mathrm{CD}, \mathrm{UC} / \mathrm{A}, \mathrm{I}$ & YES & {$[23]$} \\
\hline TLR2 & rs11938228 & 4 & A & 0.296 & 738 & Caucasian & $\downarrow$ A allele & $\mathrm{CD}, \mathrm{UC} / \mathrm{A}, \mathrm{I}$ & YES & [23] \\
\hline TLR2 & rs1816702 & 4 & $\mathrm{~T}$ & 0.138 & 738 & Caucasian & $\uparrow \mathrm{T}$ allele & $\mathrm{CD}, \mathrm{UC} / \mathrm{A}, \mathrm{I}$ & YES & [23] \\
\hline TLR2 & rs3804099 & 4 & $\mathrm{C}$ & 0.451 & 738 & Caucasian & $\uparrow \mathrm{C}$ allele & CD, UC/A, I & YES & [23] \\
\hline CD14 & rs2569190 & 5 & A & 0.474 & 738 & Caucasian & $\downarrow$ A allele & CD, UC/A, I & YES & [23] \\
\hline IL17A & rs2275913 & 6 & A & 0.354 & 738 & Caucasian & $\downarrow$ A allele & $\mathrm{CD}, \mathrm{UC} / \mathrm{A}, \mathrm{I}$ & YES & [23] \\
\hline LTA & rs909253 & 6 & G & 0.358 & 59 & Caucasian & \#\# & $\mathrm{CD} / \mathrm{A}, \mathrm{I}$ & YES & {$[41]$} \\
\hline TNF & rs 361525 & 6 & A & 0.061 & 738,82 & Caucasian & $\downarrow$ GA genotype & $\mathrm{CD}, \mathrm{UC} / \mathrm{A}, \mathrm{I}$ & YES & {$[23,39]$} \\
\hline$T N F$ & rs1800629 & 6 & A & 0.173 & 82 & Caucasian & $\downarrow \mathrm{A}$ allele & $\mathrm{CD}, \mathrm{UC} / \mathrm{A}, \mathrm{I}$ & YES & [39] \\
\hline TNF & rs1799724 & $\begin{array}{l}0 \\
6\end{array}$ & $\begin{array}{l}\mathrm{A} \\
\mathrm{T}\end{array}$ & 0.099 & $\begin{array}{l}02 \\
98\end{array}$ & Japanese & $\downarrow C$ allele & $\mathrm{CD} / \mathrm{I}$ & YES & [40] \\
\hline $\begin{array}{l}\text { TNFAIP3 } \\
\text { TNF }\end{array}$ & rs6927172 & $\begin{array}{l}0 \\
6\end{array}$ & ${ }_{G}^{1}$ & 0.175 & 738 & $\begin{array}{l}\text { Jaucasiane } \\
\text { Caucasion }\end{array}$ & $\downarrow G$ allele & $\mathrm{CD}, \mathrm{UC} / \mathrm{A}, \mathrm{I}$ & YES & {$[23]$} \\
\hline IL6 & rs10499563 & $\begin{array}{l}0 \\
7\end{array}$ & C & 0.195 & $\begin{array}{l}700 \\
738\end{array}$ & Caucasian & $\uparrow$ C allele & CD, UC/A, I & $\begin{array}{l}\text { YES } \\
\text { YES }\end{array}$ & {$[23]$} \\
\hline LY96 & rs11465996 & 8 & G & 0.358 & 738 & Caucasian & $\uparrow \mathrm{G}$ allele & $\mathrm{CD}, \mathrm{UC} / \mathrm{A}, \mathrm{I}$ & YES & [23] \\
\hline TLR4 & $\begin{array}{l}\text { rs5030728 } \\
\text { r }\end{array}$ & 9 & A & 0.305 & 738 & Caucasian & $\uparrow$ A allele & CD, UC/A, I & YES & {$[23]$} \\
\hline TLR4 & rs1554973 & 9 & $\mathrm{C}$ & 0.217 & 738 & Caucasian & $\downarrow$ C allele & CD, UC/A, I & YES & [23] \\
\hline IFNG & rs 2430561 & 12 & A & 0.280 & 738 & Caucasian & $\uparrow$ A allele & $\mathrm{CD}, \mathrm{UC} / \mathrm{A}, \mathrm{I}$ & YES & [23] \\
\hline TNFRSF1A & rs 4149570 & 12 & A & 0.336 & 738 & Caucasian & $\uparrow$ TT genotype & $\mathrm{CD}, \mathrm{UC} / \mathrm{A}, \mathrm{I}$ & YES & [23] \\
\hline TNFRSF1A & rs767455 & 12 & C & 0.508 & 738 & Caucasian & $\downarrow$ T allele & $\mathrm{CD} / \mathrm{A}, \mathrm{I}$ & YES & [32] \\
\hline МАРЗК14 & rs7222094 & 17 & $\mathrm{~T}$ & 0.381 & 738 & Caucasian & $\uparrow$ TC gentoype & $\mathrm{CD}, \mathrm{UC} / \mathrm{A}, \mathrm{I}$ & YES & [23] \\
\hline
\end{tabular}

SNP: single-nucleotide polymorphism; CHR: chromosome; MAF: minor allele frequency in Caucasian population (information obtained from: HapMap (Available online: http://hapmap.ncbi.nlm.nih.gov/) or NCBI (Available online: http://www.ncbi.nlm.nih.gov/snp) web page); CD: Crohn's disease; UC: ulcerative colitis; $\uparrow:$ better response to ant-INS; $\downarrow$ : poorer response to anti-TNF, int 96; IFNG: interferon $\gamma$; TNFRSF1A: TNF receptor superfamily 1A; MAP3K14: mitogen-activated protein kinase kinase kinase 14; \# Significant results for AT haplotype (rs1061624 and rs3397, respectively); \#\# Homozygotes for the LTA NcoI-TNFc-aa13L-aa26 haplotype 1-1-1-1. 


\section{Conclusions}

In conclusion, most of the genes associated with response to anti-TNF drugs in patients with IBD are associated with the Th17 pathway. However, data are limited, and further research is necessary to increase our knowledge of the Th17 process and understand its implication in response to anti-TNF drugs.

Acknowledgments: This study was supported by Fundación Teófilo Hernando. Rocío Prieto-Pérez has a grant from Universidad Autónoma de Madrid (research personnel in training (FPI) program 2013). The authors are grateful to Thomas O'Boyle for editorial assistance.

Author Contributions: This manuscript has been written by Rocío Prieto-Pérez and Berta Almoguera; Teresa Cabaleiro, Hakon Hakonarson, and Francisco Abad-Santos have participated in drafting the article or revising it critically for important intellectual content. All authors have given final approval of the version to be submitted and any revised version.

Conflicts of Interest: Francisco Abad-Santos has been a consultant for or investigator in clinical trials sponsored by the following pharmaceutical companies: Abbott, Alter, Chemo, Farmalíder, Ferrer, GlaxoSmithKline, Gilead, Janssen-Cilag, Kern, Normon, Novartis, Servier, Teva, and Zambon.

\section{References}

1. Boldeanu, M.V.; Silosi, I.; Ghilusi, M.; Cojocaru, M.; Biciusca, V.; Avramescu, C.S.; Cojocaru, I.M.; Ciurea, T.; Albu, D.F.; Silosi, C.A. Investigation of inflammatory activity in ulcerative colitis. Romanian J. Morphol. Embryol. 2014, 55, 1345-1351.

2. De Lange, K.M.; Barrett, J.C. Understanding inflammatory bowel disease via immunogenetics. J. Autoimmun. 2015, 64, 91-100. [CrossRef] [PubMed]

3. Molodecky, N.A.; Soon, I.S.; Rabi, D.M.; Ghali, W.A.; Ferris, M.; Chernoff, G.; Benchimol, E.I.; Panaccione, R.; Ghosh, S.; Barkema, H.W.; et al. Increasing incidence and prevalence of the inflammatory bowel diseases with time, based on systematic review. Gastroenterology 2012, 142, 46-54. [CrossRef] [PubMed]

4. Baumgart, D.C.; Carding, S.R. Inflammatory bowel disease: Cause and immunobiology. Lancet 2007, 369, 1627-1640. [CrossRef]

5. Ronnblom, A.; Samuelsson, S.M.; Ekbom, A. Ulcerative colitis in the county of Uppsala 1945-2007: Incidence and clinical characteristics. J. Crohns Colitis 2014, 4, 532-536. [CrossRef] [PubMed]

6. Prieto-Pérez, R.; Cabaleiro, T.; Dauden, E.; Abad-Santos, F. Gene polymorphisms that can predict response to anti-TNF therapy in patients with psoriasis and related autoimmune diseases. Pharmacogenom. J. 2013, 13, 297-305. [CrossRef] [PubMed]

7. Sartor, R.B. Mechanisms of disease: Pathogenesis of Crohn's disease and ulcerative colitis. Nat. Clin. Pract. Gastroenterol. Hepatol. 2006, 3, 390-407. [CrossRef] [PubMed]

8. Van Assche, G.; Rutgeerts, P. Anti-TNF agents in Crohn's disease. Expert Opin. Investig. Drugs 2000, 9, 103-111. [CrossRef] [PubMed]

9. Knight, D.M.; Trinh, H.; Le, J.; Siegel, S.; Shealy, D.; McDonough, M.; Scallon, B.; Moore, M.A.; Vilcek, J.; Daddona, P.; et al. Construction and initial characterization of a mouse-human chimeric anti-TNF antibody. Mol. Immunol. 1993, 30, 1443-1453. [CrossRef]

10. Lee, J.S.; Lee, J.H.; Lee, H.J.; Kim, M.J.; Choe, Y.H. Efficacy of early treatment with infliximab in pediatric Crohn's disease. World J. Gastroenterol. 2010, 16, 1776-1781. [CrossRef] [PubMed]

11. Zampeli, E.; Gizis, M.; Siakavellas, S.I.; Bamias, G. Predictors of response to anti-tumor necrosis factor therapy in ulcerative colitis. World J. Gastrointest. Pathophysiol. 2014, 5, 293-303. [PubMed]

12. Kim, M.J.; Lee, J.S.; Lee, J.H.; Kim, J.Y.; Choe, Y.H. Infliximab therapy in children with Crohn's disease: A one-year evaluation of efficacy comparing "top-down" and "step-up" strategies. Acta Paediatr. 2011, 100, 451-455. [CrossRef] [PubMed]

13. Dubinsky, M.C.; Mei, L.; Friedman, M.; Dhere, T.; Haritunians, T.; Hakonarson, H.; Kim, C.; Glessner, J.; Targan, S.R.; McGovern, D.P.; et al. Genome wide association (GWA) predictors of anti-TNF $\alpha$ therapeutic responsiveness in pediatric inflammatory bowel disease. Inflamm. Bowel Dis. 2010, 16, 1357-1366. [CrossRef] [PubMed] 
14. Medrano, L.M.; Taxonera, C.; Marquez, A.; Barreiro-de Acosta, M.; Gomez-Garcia, M.; Gonzalez-Artacho, C.; Perez-Calle, J.L.; Bermejo, F.; Lopez-Sanroman, A.; Martin Arranz, M.D.; et al. Role of TNFRSF1B polymorphisms in the response of Crohn's disease patients to infliximab. Hum. Immunol. 2014, 75, 71-75. [CrossRef] [PubMed]

15. Kakazu, T.; Hara, J.; Matsumoto, T.; Nakamura, S.; Oshitani, N.; Arakawa, T.; Kitano, A.; Nakatani, K.; Kinjo, F.; Kuroki, T. Type 1 T-helper cell predominance in granulomas of Crohn's disease. Am. J. Gastroenterol. 1999, 94, 2149-2155. [CrossRef] [PubMed]

16. Xavier, R.J.; Podolsky, D.K. Unravelling the pathogenesis of inflammatory bowel disease. Nature 2007, 448, 427-434. [CrossRef] [PubMed]

17. Mosmann, T.R.; Cherwinski, H.; Bond, M.W.; Giedlin, M.A.; Coffman, R.L. Two types of murine helper T cell clone. I. Definition according to profiles of lymphokine activities and secreted proteins. J. Immunol. 1986, 136, 2348-2357. [PubMed]

18. Sutton, C.E.; Lalor, S.J.; Sweeney, C.M.; Brereton, C.F.; Lavelle, E.C.; Mills, K.H. Interleukin-1 and IL-23 induce innate IL-17 production from $\gamma \delta$ T cells, amplifying Th17 responses and autoimmunity. Immunity 2009, 31, 331-341. [CrossRef] [PubMed]

19. Chung, Y.; Chang, S.H.; Martinez, G.J.; Yang, X.O.; Nurieva, R.; Kang, H.S.; Ma, L.; Watowich, S.S.; Jetten, A.M.; Tian, Q.; et al. Critical regulation of early Th17 cell differentiation by interleukin-1 signaling. Immunity 2009, 30, 576-587. [CrossRef] [PubMed]

20. Veldhoen, M.; Hocking, R.J.; Atkins, C.J.; Locksley, R.M.; Stockinger, B. TGF $\beta$ in the context of an inflammatory cytokine milieu supports de novo differentiation of IL-17-producing T cells. Immunity 2006, 24, 179-189. [CrossRef] [PubMed]

21. Smythies, L.E.; Sellers, M.; Clements, R.H.; Mosteller-Barnum, M.; Meng, G.; Benjamin, W.H.; Orenstein, J.M.; Smith, P.D. Human intestinal macrophages display profound inflammatory anergy despite avid phagocytic and bacteriocidal activity. J. Clin. Investig. 2005, 115, 66-75. [CrossRef] [PubMed]

22. Dalpke, A.; Frank, J.; Peter, M.; Heeg, K. Activation of toll-like receptor 9 by DNA from different bacterial species. Infect. Immun. 2006, 74, 940-946. [CrossRef] [PubMed]

23. Bank, S.; Andersen, P.S.; Burisch, J.; Pedersen, N.; Roug, S.; Galsgaard, J.; Turino, S.Y.; Brodersen, J.B.; Rashid, S.; Rasmussen, B.K.; et al. Associations between functional polymorphisms in the NFKB signaling pathway and response to anti-TNF treatment in Danish patients with inflammatory bowel disease. Pharmacogenom. J. 2014, 14, 526-534. [CrossRef] [PubMed]

24. Harrington, L.E.; Hatton, R.D.; Mangan, P.R.; Turner, H.; Murphy, T.L.; Murphy, K.M.; Weaver, C.T. Interleukin 17-producing CD4+ effector $\mathrm{t}$ cells develop via a lineage distinct from the $\mathrm{t}$ helper type 1 and 2 lineages. Nat. Immunol. 2005, 6, 1123-1132. [CrossRef] [PubMed]

25. Fuss, I.J.; Heller, F.; Boirivant, M.; Leon, F.; Yoshida, M.; Fichtner-Feigl, S.; Yang, Z.; Exley, M.; Kitani, A.; Blumberg, R.S.; et al. Nonclassical CD1d-restricted NK T cells that produce IL-13 characterize an atypical Th2 response in ulcerative colitis. J. Clin. Investig. 2004, 113, 1490-1497. [CrossRef] [PubMed]

26. Nograles, K.E.; Brasington, R.D.; Bowcock, A.M. New insights into the pathogenesis and genetics of psoriatic arthritis. Nat. Clin. Pract. 2009, 5, 83-91. [CrossRef] [PubMed]

27. Patel, D.D.; Lee, D.M.; Kolbinger, F.; Antoni, C. Effect of IL-17a blockade with secukinumab in autoimmune diseases. Ann. Rheum. Dis. 2013, 72 (Suppl. 2), ii116-ii123. [CrossRef] [PubMed]

28. Wong, M.; Ziring, D.; Korin, Y.; Desai, S.; Kim, S.; Lin, J.; Gjertson, D.; Braun, J.; Reed, E.; Singh, R.R. $\mathrm{TNF} \alpha$ blockade in human diseases: Mechanisms and future directions. Clin. Immunol. 2008, 126, 121-136. [CrossRef] [PubMed]

29. Quetglas, E.G.; Mujagic, Z.; Wigge, S.; Keszthelyi, D.; Wachten, S.; Masclee, A.; Reinisch, W. Update on pathogenesis and predictors of response of therapeutic strategies used in inflammatory bowel disease. World J. Gastroenterol. 2015, 21, 12519-12543. [CrossRef] [PubMed]

30. Hlavaty, T.; Pierik, M.; Henckaerts, L.; Ferrante, M.; Joossens, S.; van Schuerbeek, N.; Noman, M.; Rutgeerts, P.; Vermeire, S. Polymorphisms in apoptosis genes predict response to infliximab therapy in luminal and fistulizing Crohn's disease. Aliment. Pharmacol. Ther. 2005, 22, 613-626. [CrossRef] [PubMed]

31. Jürgens, M.; Laubender, R.P.; Hartl, F.; Weidinger, M.; Seiderer, J.; Wagner, J.; Wetzke, M.; Beigel, F.; Pfennig, S.; Stallhofer, J.; et al. Disease activity, ANCA, and IL23R genotype status determine early response to infliximab in patients with ulcerative colitis. Am. J. Gastroenterol. 2010, 105, 1811-1819. [CrossRef] [PubMed] 
32. Matsukura, H.; Ikeda, S.; Yoshimura, N.; Takazoe, M.; Muramatsu, M. Genetic polymorphisms of tumour necrosis factor receptor superfamily $1 \mathrm{~A}$ and $1 \mathrm{~B}$ affect responses to infliximab in japanese patients with Crohn's disease. Aliment. Pharmacol. Ther. 2008, 27, 765-770. [CrossRef] [PubMed]

33. Moroi, R.; Endo, K.; Kinouchi, Y.; Shiga, H.; Kakuta, Y.; Kuroha, M.; Kanazawa, Y.; Shimodaira, Y.; Horiuchi, T.; Takahashi, S.; et al. FCGR3A-158 polymorphism influences the biological response to infliximab in Crohn's disease through affecting the ADCC activity. Immunogenetics 2013, 65, 265-271. [PubMed]

34. Hampe, J.; Franke, A.; Rosenstiel, P.; Till, A.; Teuber, M.; Huse, K.; Albrecht, M.; Mayr, G.; de La Vega, F.M.; Briggs, J.; et al. A genome-wide association scan of nonsynonymous SNPs identifies a susceptibility variant for Crohn disease in ATG1611. Nat. Genet. 2007, 39, 207-211. [CrossRef] [PubMed]

35. Rioux, J.D.; Xavier, R.J.; Taylor, K.D.; Silverberg, M.S.; Goyette, P.; Huett, A.; Green, T.; Kuballa, P.; Barmada, M.M.; Datta, L.W.; et al. Genome-wide association study identifies new susceptibility loci for Crohn disease and implicates autophagy in disease pathogenesis. Nat. Genet. 2007, 39, 596-604. [CrossRef] [PubMed]

36. Koder, S.; Repnik, K.; Ferkolj, I.; Pernat, C.; Skok, P.; Weersma, R.K.; Potocnik, U. Genetic polymorphism in ATG16l1 gene influences the response to adalimumab in Crohn's disease patients. Pharmacogenomics 2015, 16, 191-204. [CrossRef] [PubMed]

37. Duerr, R.H.; Taylor, K.D.; Brant, S.R.; Rioux, J.D.; Silverberg, M.S.; Daly, M.J.; Steinhart, A.H.; Abraham, C.; Regueiro, M.; Griffiths, A.; et al. A genome-wide association study identifies IL23R as an inflammatory bowel disease gene. Science 2006, 314, 1461-1463. [CrossRef] [PubMed]

38. Lacruz-Guzmán, D.; Torres-Moreno, D.; Pedrero, F.; Romero-Cara, P.; Garcia-Tercero, I.; Trujillo-Santos, J.; Conesa-Zamora, P. Influence of polymorphisms and TNF and IL1 $\beta$ serum concentration on the infliximab response in Crohn's disease and ulcerative colitis. Eur. J. Clin. Pharmacol. 2013, 69, 431-438. [CrossRef] [PubMed]

39. López-Hernández, R.; Valdes, M.; Campillo, J.A.; Martinez-Garcia, P.; Salama, H.; Salgado, G.; Boix, F.; Moya-Quiles, M.R.; Minguela, A.; Sanchez-Torres, A.; et al. Genetic polymorphisms of tumour necrosis factor $\alpha$ (TNF- $\alpha$ ) promoter gene and response to TNF- $\alpha$ inhibitors in Spanish patients with inflammatory bowel disease. Int. J. Immunogenet. 2014, 41, 63-68. [CrossRef] [PubMed]

40. Ozeki, T.; Furuya, Y.; Nagano, C.; Matsui, C.; Takayanagi, R.; Yokoyama, H.; Yamada, Y. Analysis of linkage between lymphotoxin $\alpha$ haplotype and polymorphisms in $5^{\prime}$-flanking region of tumor necrosis factor $\alpha$ gene associated with efficacy of infliximab for Crohn's disease patients. Mutat. Res. 2006, 602, 170-174. [CrossRef] [PubMed]

41. Taylor, K.D.; Plevy, S.E.; Yang, H.; Landers, C.J.; Barry, M.J.; Rotter, J.I.; Targan, S.R. ANCA pattern and LTA haplotype relationship to clinical responses to anti-TNF antibody treatment in Crohn's disease. Gastroenterology 2001, 120, 1347-1355. [CrossRef] [PubMed]

42. Barreiro-de Acosta, M.; Ouburg, S.; Morré, S.A.; Crusius, J.B.; Lorenzo, A.; Potel, J.; Salvador-Peña, A.; Domínguez-Muñoz, J.E. NOD2, CD14 and TLR4 mutations do not influence response to adalimumab in patients with Crohn's disease: A preliminary report. Rev. Esp. Enferm. Dig. 2010, 102, 591-595. [CrossRef] [PubMed]

43. Fujino, S.; Andoh, A.; Bamba, S.; Ogawa, A.; Hata, K.; Araki, Y.; Bamba, T.; Fujiyama, Y. Increased expression of interleukin 17 in inflammatory bowel disease. Gut 2013, 52, 65-70. [CrossRef]

(C) 2016 by the authors; licensee MDPI, Basel, Switzerland. This article is an open access article distributed under the terms and conditions of the Creative Commons by Attribution (CC-BY) license (http:/ / creativecommons.org/licenses/by/4.0/). 